\title{
NEMATODE SURVEY OF PLANTAIN ORCHARDS IN JATAÍ AND PEROLÂNDIA - GOIÁS STATE, BRAZIL
}

\author{
Victor Hugo Assis Hoff Brait ${ }^{1}$, Luciana Celeste Carneiro ${ }^{1}$, Paulo Afonso Ferreira ${ }^{2}$
}

\footnotetext{
${ }^{1}$ Federal University of Jataí, Brazil. E-mail: vhbrait@ gmail.com, luciana.celeste.carneiro@ gmail.com

${ }^{2}$ Federal University of Mato Grosso, Brazil. E-mail: paulofonso@ufmt.br
}

\section{ABSTRACT}

Banana is an important fruit for Brazil for it is the most produced and consumed fruit in natura. As every cultivated plant, banana trees have their yield affected by pests and diseases. Among the most detrimental pests are the nematodes, which are sadly also ubiquitous in banana orchards. In Jataí and Perolândia, municipalities of the state of Goiás, Brazil, there is few data regarding the genera and population densities of plant parasitic nematodes in banana orchards. Therefore, a survey from 17 orchards is presented in this paper. All of them had plantains (AAB) planted, since it is the prevalent cultivated genetic group in the region. The nematode extraction method consisted in sieving followed by centrifugal separation. Together with the nematode survey, a poll was presented to farmers, which encompassed questions about the general orchard management. Helicotylenchus was the prevailing genus in all samples. Meloidogyne and Pratylenchus also presented high population density in some areas.

Keywords: Musa paradisiaca, Helicotylenchus, Pratylenchus brachyurus, Meloydogine spp.

\section{LEVANTAMENTO DE NEMATOIDES NOS MUNICÍPIOS DE JATAÍ E PEROLÂNDIA - GOIÁS, BRASIL}

\section{RESUMO}

A banana é uma fruta importante no Brasil, pois é a mais produzida e consumida na forma in natura. Como toda espécie cultivada, a bananeira é acometida por diferentes problemas fitossanitários. Entre os mais prejudiciais estão as doenças causadas por nematoides, que acarretam prejuízos em todo o mundo. Na região de Jataí e Perolândia (GO) há poucos dados sobre os nematoides presentes nos bananais. Portanto, foi feito um levantamento dos principais nematoides, 
em bananais cultivados com o subgrupo Terra (AAB), o grupo genômico predominante na região. Amostras de solo e raízes foram obtidas de 17 propriedades e a extração dos nematoides foi feita por peneiramento e centrifugação. Conjuntamente com as análises foi feita uma investigação do manejo da cultura. $\mathrm{O}$ nematoide predominante nas amostras foi Helicotylenchus spp., que apresentou a maior frequência. Meloidogyne spp. e Pratylenchus spp. também foram encontrados com expressiva densidade populacional em algumas áreas.

Palavras-chave: Musa paradisiaca, Helicotylenchus, Pratylenchus brachyurus, Meloydogine spp.

\section{INTRODUCTION}

According to an annual survey from Instituto Brasileiro de Geografia e Estatística (Brazilian Institute for Geography and Statistics- IBGE), a governmental organization linked to the Brazilian Ministry of Economy, last year's Brazilian banana gross production reached 6,710,436 tons. Considering that only 61,400 tons account for exports, about $99.19 \%$ from the gross production reached domestic markets (FAO, 2018).

Despite the great national banana production, many producers find it difficult to reach or get closer to the maximum economic yield. Crop protection, especially nematode management, is among the obstacles faced by banana growers. (LUQUINI et al., 2019; GODEFROID et al., 2017; AGUIERRE et al.; 2016). In the municipality of Jataí, in the state of Goiás, Brazil, symptoms of plant parasitic nematodes (PPNs) can be noticed in banana orchards. However, for an assertive management, it is important to know the genera and species present in the orchards. Only then it is possible to understand the relation between PPNs and plant yield. The present survey tries to fill the gap of information on nematode presence in banana orchards from Jataí and Perolândia in the state of Goiás, Brazil.

\section{MATERIAL AND METHODS}

Soil and root samples were collected from 17 commercial plantain orchards between November 2017 and January 2018. All the orchards were either in Jataí or Perolândia, municipalities in the state of Goiás, Brazil. The orchards were found with the help of the local 
office of Technical Assistance and Rural Extension Company from the State of Goiás. When visited, the respective orchards had their GPS coordinates recorded.

Soil and root sampling followed a systematic approach due to the clustering characteristic of nematodes distribution. In each orchard, 10 subsamples were collected in a uniform hectare (soil type, plant age and orchard management). Each subsample included root tissue and soil from the rhizosphere from one or two plants. Subsamples were mixed together and $1000 \mathrm{dm}^{3}$ of soil and some root tissue were set aside for analysis.

Nematode extraction occurred at Agronomic Research Nucleus at Federal University of Goiás - Campus Jataí and Exata Agro-Industrial Laboratory, both in Jataí.

Extraction from soil samples followed Jenkins (1964) method. $200 \mathrm{~cm}^{3}$ of soil and 1800 $\mathrm{cm}^{3}$ of water were mixed together in a bucket following sieving in 20 and 400 mesh. The retained material on the 400-mesh sieve was poured into 50-ml tubes and centrifuged at $1800 \mathrm{rpm}$ for 5 minutes. The supernatant was discarded and a solution of $400 \mathrm{~g}^{-1} \mathrm{l}^{-1}$ sucrose-water was poured into the tube and centrifuged once more at $1800 \mathrm{rpm}$, but only for $1 \mathrm{~min}$. The supernatant was poured through a 500 mesh sieve, from which the retained material was washed out and kept in plastic pots. The final water-nematode suspension added up to $10 \mathrm{~cm}^{3}$.

Root nematode extraction followed Coolen \& D'Herde (1972) method. Five grams of roots were washed, dried with towel paper, cut into 1 to $2 \mathrm{~cm}$ pieces then crushed in a blender for 40 seconds. The following steps were the same for Jenkins (1964) method, except the kaolin addition to the centrifuge tubes for cementation. The nematode-containing suspension was put in water bath until it reached $60^{\circ} \mathrm{C}$, following formaldehyde addition for fixation.

In Laboratório de Fitopatologia da Universidade Federal de Goiás - Regional Jataí (Plant Pathology Laboratory of Federal University of Goiás - Jataí Branch), nematodes were identified and counted. A specific blade for counting nematodes was used for nematode quantification and genera identification. Nematode frequencies, absolute densities and relative densities for each orchard were determined.

While nematodes were sampled and analysed, banana growers were polled, giving information on fundamental management techniques (irrigation, fertilization, Cosmopolites sordidus and nematode management). In certain orchards more information was gathered, e.g. the preceding crop. The data was used for assessing banana production in those cities. 


\section{RESULTS AND DISCUSSION}

The genus Helicotylenchus was observed in all samples (Table 1). Similar results were also obtained in other surveys throughout Brazil (LUQUINI et al., 2019; ALMEIDA et al., 2018; NEVES et al., 2009). The species Pratylenchus brachyurus was observed in half of analysed samples, both in soil and roots. That can be explained by the prevalence of the nematode in CentralWest Brazil, where it is known to cause damage to main crops, such as soybean and maize. The genus Meloidogyne was also found in half of soil samples.

Table 1. Frequency of nematode (F) and number of samples (NS) in which they were found. Nematode survey of plantain orchards in Jataí and Perolândia - Goiás State, Brazil.

\begin{tabular}{lrrrr}
\hline Genus & F Soil (\%) & F Root (\%) & NS Soil & NS Root \\
\hline Helicotylenchus & 100.00 & 100.00 & 17 & 17 \\
Pratylenchus & 47.06 & 47.06 & 8 & 8 \\
Meloidogyne (juvenile) & 64.71 & 17.65 & 11 & 3 \\
Mesocriconema & 23.53 & 0 & 4 & 0 \\
Tylenchorhynchus & 5.88 & 0 & 1 & 0 \\
\hline
\end{tabular}

The genus Helicotylenchus was also predominant considering population densities per orchard (Figures 1 and 2). In the few orchards where this did not happen, Meloidogyne was the predominant genus (soil samples 4, 6, 8, and 13 and root sample 6), in which it reached a relative population density higher than 50\%. Pratylenchus showed low population densities compared to the previously mentioned two genera.

The genus Helicotylenchus reached the highest absolute population density among root samples (Figure 3). For soil samples the highest density was found for Meloidogyne. Pratylenchus density in root sample 11 is noteworthy, since it is much higher than in other samples. In any other orchard it did not exceeded 300 specimens per $5 \mathrm{~g}$ of root. The species of Pratylenchus in that sample was Pratylenchus brachyurus, curiously not considered a key-pest of banana. 


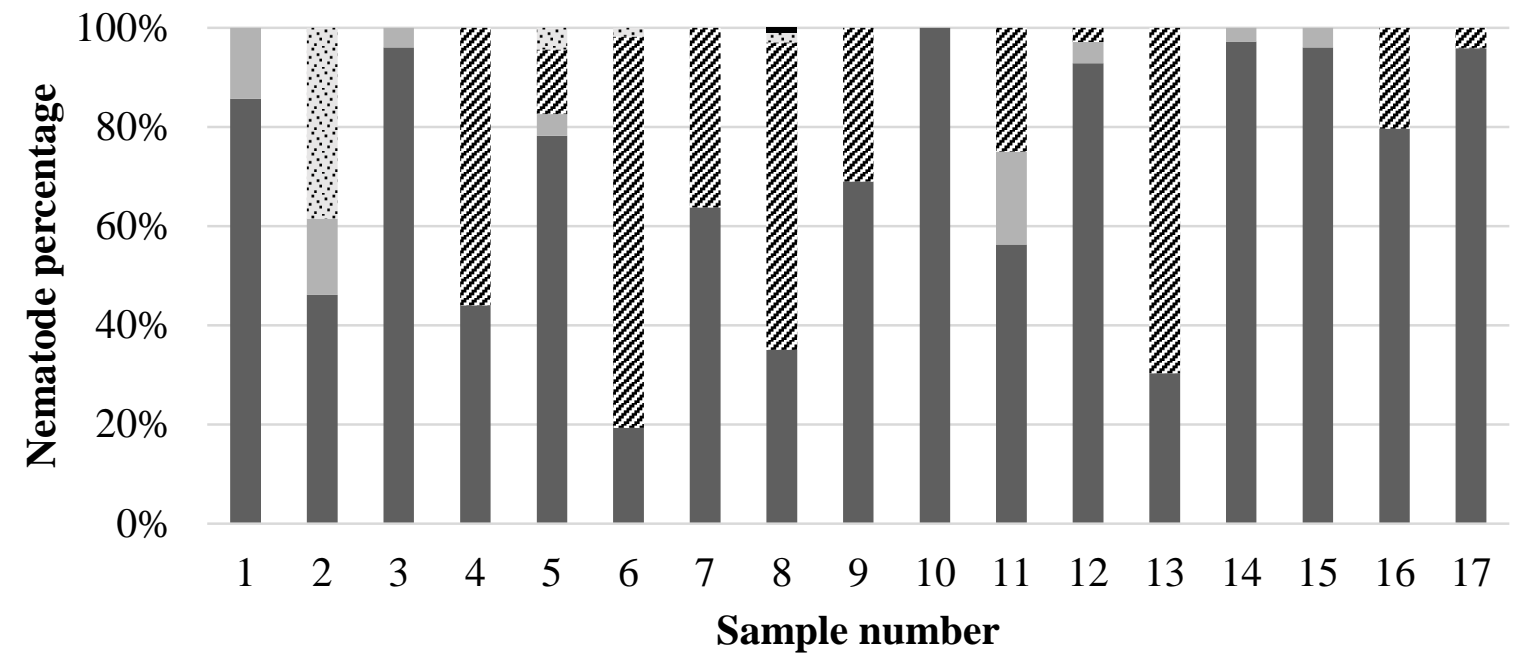

- Helicotylenchus

Mesocriconema
Pratylenchus

- Tylenchorhynchus
\# Meloidogyne

Figure 1. Nematode relative population density per soil sample. Nematode survey of plantain orchards in Jataí and Perolândia - Goiás State, Brazil.

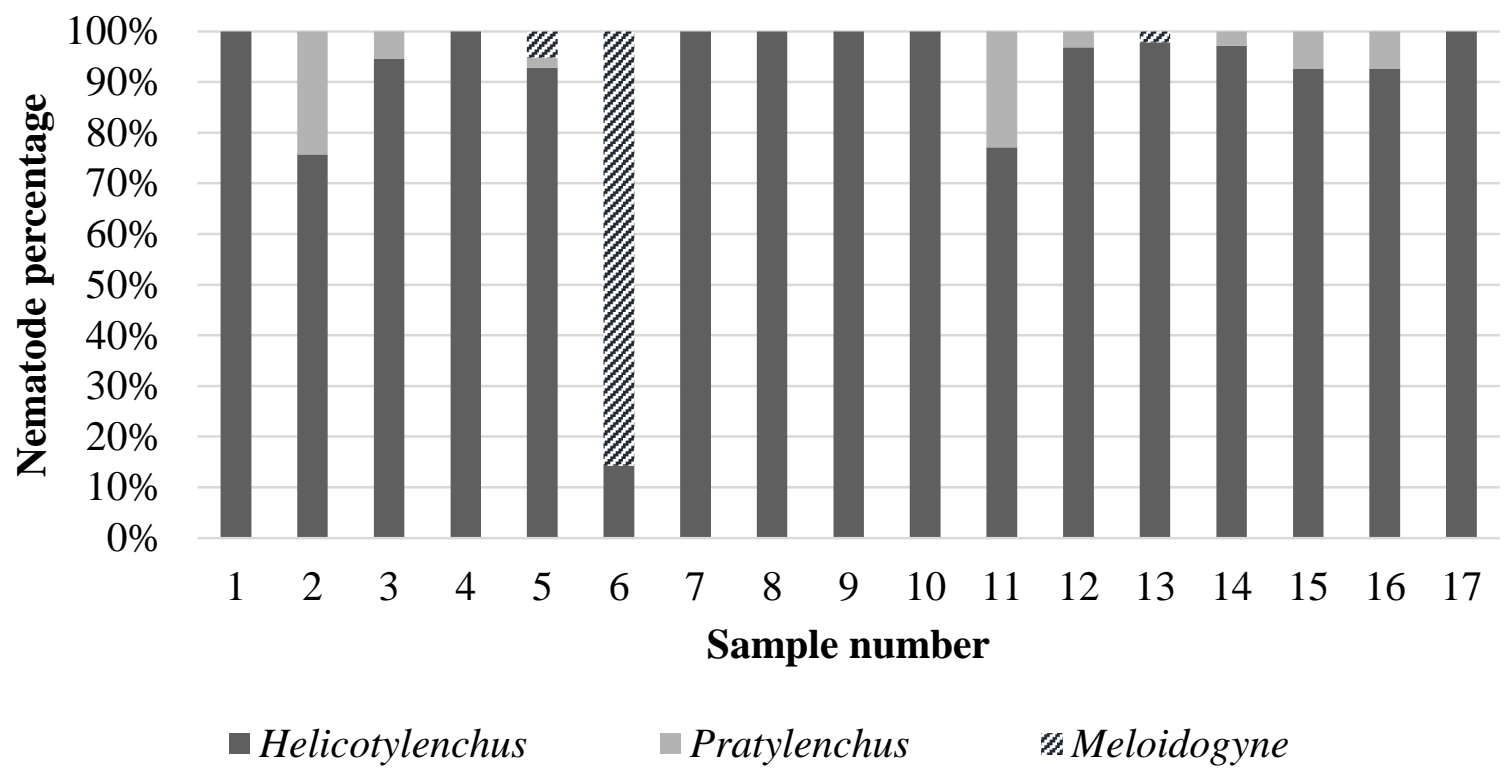

Figure 2. Nematode relative population density per root sample. Nematode survey of plantain orchards in Jataí and Perolândia - Goiás State, Brazil. 


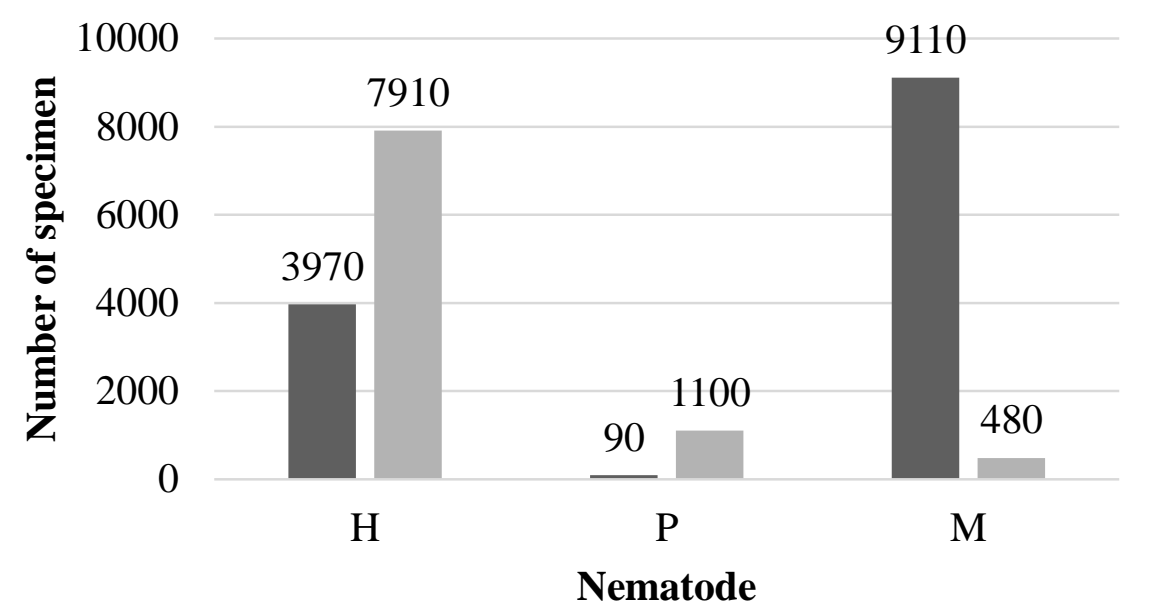

nMPD Soil Specimens/200cm3 $\square$ NMPD Root Specimens/5g

Figure 3. Nematode maximum population density (NMPD). Helicotylenchus spp. (H), Pratylenchus brachyurus (P) and Meloidogyne spp. (M). Nematode survey of plantain orchards in Jataí and Perolândia - Goiás State, Brazil.

It was also possible to have an overview on plantain production from the results of the poll taken by growers. Unfortunately, elementary management practices are disregarded (Figure 4). A fundamental rule of fruit production is the management of water at the right time. Thus, an orchard under dry conditions should have an irrigation system available. Not a single visited orchard was irrigated. Consequently, trees suffered from water stress and had their performance affected. Another neglected elementary practice is fertilizing. Nutrients, especially potassium, are essential for banana production. However, only $47 \%$ of the growers fertilize their plants. At some properties the responsible technician was not available, that is the reason for the lack of some information.

Orchard protection against pests is also of great importance. Cosmopolites sordidus, also known as banana weevil, caused damage to the visited orchards. Many toppled plants with necrotic holes in their rhizome could be observed. Management practice information is freely available for growers, yet few take interest in it. The same happens with nematode management. However, in that case, growers do not know the biological nature of the pest. Fortunately, Radopholus similis and Pratylenchus coffeae, the most aggressive nematodes to banana trees, were not found in any of the orchards (COYONE et al., 2013). 
A

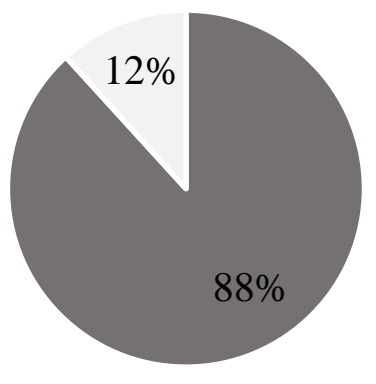

- Not irrigated No info

C

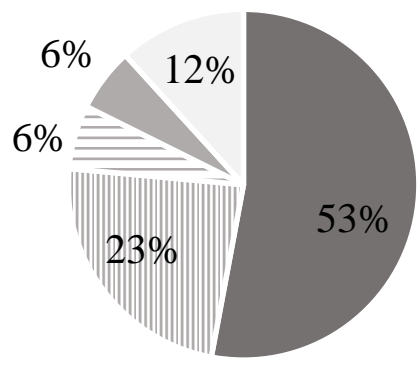

- No management

$=$ Endosulfan

No info

\section{B}

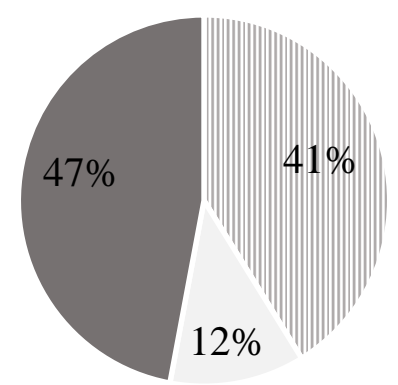

|II Not fertilized No info

- Fertilized

D

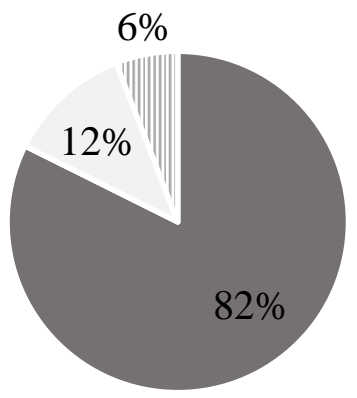

- No management No info $\mid$ Endosufan

Figure 4. Percentage of irrigated (A) and fertilized (B) orchards; percentage of orchards where Cosmopolites sordidus (C) and nematodes (D) are managed. Nematode survey of plantain orchards in Jataí and Perolândia - Goiás State, Brazil.

The present survey shows the prevalence of the genus Helicotylenchus. That is not a surprise since other researchers found similar results (LUQUINI et al., 2019; ALMEIDA et al.; 2017; SPEIJER \& DE WAELE, 2001; SPEIJER et al., 2001). Its damage potential was evaluated by a group of researchers in Central America. They showed that even not being as harmful as other PPNs, like Praylenchus coffeae and Radopholus similis, Helicotylenchus multicinctus can interfere at banana trees' performance (MOENS et al., 2006). That being so, it is possible that this nematode is damaging orchards from Jataí and Perolândia. A management strategy is clearly necessary. 
According to some authors some species of Meloidogyne may cause more damage to banana trees than Helicotylenchus multicinctus. In the Philippines, yield loss of 26\% to 57\% was reported in some experiments (MOENS et al., 2006). In Jataí and Perolândia this nematode was found in more than $50 \%$ of the orchards. Although the presence of Meloidogyne spp. is not the main yield-limiting factor, monitoring is necessary.

Pratylenchus brachyurus is not known as an important nematode for bananas and plantains. It is rarely associated with the crop (LUQUINI et al., 2019). In a survey from 67 banana orchards in Nigeria, Pratylenchus brachyurus was associated with roots in only two. The highest population density observed was 19 specimens per $5 \mathrm{~g}$ of root (SPEIJER et al., 2001). In the present survey, the highest densities observed for Pratylenchus spp. were 260 and 1100 specimens per $5 \mathrm{~g}$ of roots. The preceding crop may explain these numbers. Forage, belonging to the genus Brachiaria, was cultivated in both orchards less than 3 years before nematode sampling. The genus is known as a Pratylenchus brachyurus host. It is possible that these plants played a role in the multiplication of Pratylenchus brachyurus until crop replacement.

Initially, a high frequency of Radopholus similis, the burrowing nematode, was expected. It was reported in many Brazilian orchards (ALMEIDA et al., 2018; NEVES et al., 2009). The species is considered of high importance to banana and plantain due to its wide distribution and damage potential. Coyone et al. (2013) noticed suppression in root weight and higher necrosis percentage when compared to other banana-related PPNs. Growers from Jataí and Perolândia should make good use of exclusion measures to avoid Radopholus similis entrance to their orchards.

\section{CONCLUSION}

Three nematode genera presented high frequency, Helicotylenchus, Pratylenchus and Meloidogyne. Among those Helicotylenchus was the predominant, present in all sampled areas. Moreover, the most known aggressive species to plantain were not found, namely Pratylenchus coffeae and Radopholus similis. 


\section{REFERENCES}

AGUIERRE, O.; CHÁVEZ, C.; GIRAUD, A.; ARAYA, M. 2016. Frequencies and population densities of plant-parasitic nematodes on banana (Musa AAA) plantations in Ecuador from 2008 to 2014. Agronomía Colombiana, Bogotá, v. 34, n. 1, p. 61-73.

ALMEIDA, N.O.; TEIXEIRA, R.A.; CARNEIRO, F.A.; OLIVEIRA, C.M. de; RIBEIRO, V.A.; LOBO JÚNIOR, M.; ROCHA, M.R. 2018. Occurrence and correlations of nematodes, Fusarium oxysporum and edaphic factors on banana plantations. Journal of Phytopathology, v. 166, n. 4, p. 265-272. https://doi.org/10.1111/jph.12683

COOLEN, W. A.; D'HERDE C. J. 1972. A Method for the quantitative extraction of nematodes from plant tissue. Ghent State Nematology and Entomology Research Station, Ghent, 770.

COYONE, D.L.; OMOWUMI, A.; ROTIFA, I. AFOLAMI, S.O. 2013. Pathogenicity and damage potential of five species of plant-parasitic nematodes on plantain (Musa spp., AAB genome) cv. Agbagba. Nematology, v.15, n.5, p. 589-599. https://doi.org/10.1163/15685411-00002704

FAO - Food and Agriculture Organization of the United Nations. 2018. Banana Market Review: Preliminary results for 2018. Rome. 12pp. Licence: CC BY-NC-SA 3.0 IGO.

GODEFROID, M.; TIXIER, P.; CHABRIER, C.; DJIGAL, D.; QUÉNÉHERVÉ, 2017. Association of soil type and previous crop with plant-feeding nematode communities in plantain agrosystems. Applied Soil Ecology, v. 113, p. 63-70. https://doi.org/1016/j.apsoil.2017.01.012

IBGE - Instituto Brasileiro de Geografia e Estatística, 2019. Levantamento sistemático da produção agrícola. Available at:<https://sidra.ibge.gov.br/home/lspa/brasil > Accessed on: May 30, 2020.

JENKINS, W.R. 1964. A rapid centrifugal-flotation technique for separating nematodes from soil. Plant Disease Reporter, Beltsville, v. 48, n. 9, p 692.

LUQUINI, L.; BARBOSA, D.; HADDAD, F.; FERREIRA, C.F.; AMORIM, E.P. 2019. Nematode survey and biochemical characterization of Meloidogyne spp. in a main banana production area in Brazil. Crop Protection, v. 117, p. 94-99. https://doi.org/10.1016/j.cropro.2018.11.018

MOENS, T.; ARAYA, M., SWENNEN, R.; DE WAELE, D. 2006. Reproduction and pathogenicity of Helicotylenchus multicinctus, Meloidogyne incognita and Pratylenchus coffeae, and their interaction with Radopholus similis on Musa. Nematology, v.8, n.1, p. 4548. https://doi.org/10.1163/156854106776179999

NEVES, W. S.; DIAS, M. S. C.; BARBOSA, J. G. 2009. Flutuação Populacional de Nematoides em Bananais de Minas Gerais e Bahia (Anos 2003 a 2008). Nematologia Brasileira, v. 33, n. 4, p. 281-285. http://doi.org/10.1590/S0100-29452009000100016

SPEIJER, P.R.; DE WAELE, D. 2001. Nematodes associated with East African Highland cooking bananas and cv. Pisang Awak (Musa spp.) in Central Uganda. Nematology, v.3, n.6, p. 535541. https://doi.org/10.1163/156854101753389149

SPEIJER, P.R.; ROTIMI, M.O.; DE WAELE, D. 2001. Plant parasitic nematodes associated with plantain (Musa spp., AAB-group) in southern Nigeria and their relative importance compared to other biotic constraints. Nematology, v.3, n.5., p. 423-436. https://doi.org/10.1163/156854101753250755 